\title{
The Potential Role of Energy-from-Waste Air Pollution Control Residues in the Industrial Ecology of Cement
}

\author{
Stegemann, J.A. ${ }^{1}$ \\ Centre for Resource Efficiency \& the Environment \\ University College London, WC1E 6BT, United Kingdom
}

\begin{abstract}
Industrial ecology draws an analogy between industrial activity and natural ecosystems with the inherent implication that, in its ideal form, an industrial ecosystem cycles resources efficiently, with minimisation of waste. Industrial symbiosis between the cement and other industries can make a substantial contribution to sustainability. About 3.6 Gt of cement were produced globally in 2011, consuming more than 5 Gt of raw materials and about $11 \%$ of total industrial energy, and leading to about $7 \%$ of global $\mathrm{CO}_{2}$ emissions. In the same year, global generation of municipal solid waste (MSW) was estimated at $1.3 \mathrm{Gt}$, of which about $16 \%$ was thermally processed, usually by combustion to generate energy-from-waste (EfW). This equates to about $2.1 \%$ of total industrial energy consumption, but would generate about 6 Mtpa of air pollution control (APC) residues. Use of these EfW APC residues in blended cements has been suggested, but they contain soluble toxic elements and are classified as hazardous wastes in most jurisdictions. This paper discusses the effects of incorporating EfW APC residues on the technical performance of blended cements, and on several characteristics of importance for the environmental acceptability of this practice, including 1) total inorganic pollutant concentrations in blended cements, 2) pH-dependent leachability of toxic metal pollutants, e.g., according to BS EN 12457-2, and DD CEN/TS 15364, and 3) diffusion controlled leaching of monolithic blended cement pastes, e.g., according to EA NEN 7375.

Potential pollutants, especially $\mathrm{Pb}$ and $\mathrm{Zn}$, but also $\mathrm{Cd}, \mathrm{Hg}, \mathrm{Sb}, \mathrm{Sn}$ and $\mathrm{Se}$, were found to be enriched in EfW APC residues relative to cements. Apart from their potential to pollute the environment, metals in APC residues can affect cement hydration and hardening, and this has been observed. EfW APC residues also contain high levels of several elements that are problematic for quality control of blended cements, notably chloride, which causes steel reinforcement corrosion, and alkalis (Na, K), implicated in the destructive alkali-silica reaction. Although leaching data for both granular and monolithic samples suggest that the mobility of low concentrations of metal pollutants is reduced in cement-based matrices, leachability of chloride remains high, and leaching of soluble constituents in APC residues can also be expected to increase paste porosity over time. Furthermore, the literature indicates that pozzolanic or cementing properties of EfW APC residues are not sufficiently strong or reliable to justify their use as a cement replacement, and there is also the potential for components of APC residues to cause other deleterious expansion reactions in cement-based materials. Therefore, industrial ecology cannot solve the problem of management of EfW APC residues through incorporating them in blended cements without radically re-thinking the principle that "dilution is not the solution to pollution", which underlies much waste management legislation. Relaxation of these principles would also have undesirable implications for numerous other hazardous wastes. Management of such wastes by blending into cements might seem convenient, but could ultimately lead to wide uncontrolled dispersal of pollutants, especially in cement product recycling, and undermine the quality of blended cements.
\end{abstract}

\section{Originality}

This paper considers the technical benefits and environmental acceptability of using EfW APC residues in blended cement production, with a focus on the fate and behaviour of the toxic metal concentrations in the APC residues. It summarises the available information on this subject, and provides a critical analysis and discussion aimed at the cement and waste management industries, as well as policymakers, to assist in decision-making.

Keywords: symbiosis, metabolism, waste-to-energy, municipal solid waste incinerator ash

\footnotetext{
1j.stegemann@ucl.ac.uk, Tel +44 2076797370
} 


\section{Introduction}

\subsection{Industrial Ecology}

Over the past three decades, the concept of industrial ecology has emerged as central to the development of resource efficiency and environmental management (e.g., Frosch R.A. \&. Gallopoulos N.E., 1989; Chertow M.R., 2000). With its comparable need to make efficient use of resources, industrial activity can be considered to resemble a natural ecosystem, where a network of interdependent companies is analogous to organisms, the market place is the environment, innovation is adaptation, and business competition leads to survival of the fittest just as natural selective pressures result in evolution of species in nature. Manufacturing is analogous to anabolic, and waste management to catabolic, metabolism. An important difference is that a plethora of organisms and processes fills all available ecological niches, with waste from one organism becoming food for another, so that no resources are wasted in highly evolved natural ecosystems, whereas considerable waste still occurs in our relatively primitive industrial ecosystems. Our society currently uses water and energy inefficiently, squanders valuable materials resources and pollutes the environment through emissions to air, water and land. It is therefore recognised that further evolution of our industrial ecosystems is essential to fully cycle the required resources and avoid the damage to the environment associated with linear use of resources.

\subsection{Consumption of Resources by the Cement Industry}

Concrete is purportedly the single most widely used material in the world (Crow J.M., 2008), and the World Business Council for Sustainable Development's Cement Sustainability Initiative (CSI) has collected data from the producers of $25 \%$ of the total global cement supply, which indicate that about 3.6 Gt of cementitious materials were produced in 2011, using about 2.7 Gt of Portland cement clinker (WBCSD, 2012). WBCSD figures also indicate that cement production consumed about $11 \times 10^{9} \mathrm{GJ}$ of energy in 2011, including both thermal and electrical energy, which represents $11 \%$ of total global industrial energy (based on figures from the IEA, 2012). The calcination process to produce clinker, including fuel combustion, was associated with about $2.3 \mathrm{Gt}$ of $\mathrm{CO}_{2}$ emissions in 2011 (based on WBCSD, 2012), contributing approximately $7 \%$ of total global $\mathrm{CO}_{2}$ emissions (Olivier J.G.J. et al., 2012). Furthermore, assuming a raw material to clinker ratio of 1.6 (Nisbet M.A., 2002), it can be calculated that cementitious materials incorporated more than 5 Gt of raw materials in 2011. It is therefore evident that the cement industry is associated with consumption of a significant proportion of global resources, and that more efficient management of these resources is important to sustainability.

\subsection{Resource Recovery from Waste}

The global production of MSW, i.e., waste from domestic households, was estimated at $1.3 \mathrm{Gt}$ in 2011 and is expected to double by 2025 (Hoornweg D. \& Bhada-Tata P., 2012). According to the accepted "waste hierarchy", which prioritises waste management strategies to support the most efficient and sustainable use of the resources present in waste, re-use and recycling are preferable to energy recovery and disposal. Nevertheless, the limited available data about global MSW management practices suggest that about $60 \%$ of MSW is disposed of to land, with variable control of associated environmental impacts, whereas about $16 \%$ is combusted, usually generating electricity and sometimes heat (Hoornweg D. \& Bhada-Tata P., 2012). Assuming that MSW has a calorific value of $10 \mathrm{MJ} / \mathrm{kg}$ (CEWEP, 2010), it can be calculated that about $2.1 \times 10^{9} \mathrm{GJ}$ pa of energy are released from MSW, which represents about $2.1 \%$ of global total industrial energy, i.e., about a fifth of the energy consumed globally by the cement industry (see 1.2). EfW, whether obtained by combustion or other processes, also yields uncombustible mineral ash residues, which represent about $30 \%$ of the original waste mass, i.e., presently about $0.06 \mathrm{Gtpa}$, globally. About $90 \%$ of this material is bottom ash from the combustion grate. The rest, about 6 Mtpa globally, is APC residue that results from cleaning the gas emissions, and contains fly ash and usually calcium or sodium salts from scrubbing of acid gases. Bottom ash contains a valuable metal fraction that is recovered for recycling, while the mineral residue after metals removal is sometimes utilised in construction applications, including cement and concrete (e.g., ISWA, 2006). Bottom ash is not usually 
considered to be a hazardous waste in most jurisdictions, but APC residue is generally considered hazardous due to the excess alkalinity (corrosivity) resulting from acid gas scrubbing and high concentrations of soluble toxic metals associated with the fly ash. EfW APC residues therefore represent a hazardous waste disposal problem.

\subsection{Opportunities for Industrial Symbiosis in the Cement Industry}

In a natural ecosystem, resources are shared and cycled between members for mutual benefit in symbiotic relationships. In industrial symbiosis, the by-products of one industry become the raw materials for another. A considerable degree of such symbiosis is already embedded in many industries, as obtaining energy and materials resources at lower cost in this way has always been good business. Industrial symbiosis has occurred in the cement industry since long before the popularisation of the concept of industrial ecology (e.g., by Vigon B., 2002). The three most common practices have been: 1) use of wastes with high calorific value to replace fossil fuels for calcination of the raw materials into clinker in the cement kiln, 2) replacement of Portland cement clinker with pozzolanic wastes and diluents to produce blended cements, and 3) replacement of raw material feeds (limestone, clay and supplements) to the cement kiln with mineral wastes. Industrial symbiosis also occurs in manufacture of concrete, with replacement of natural aggregate by waste.

When resources become more scarce and costly and waste builds up in an ecosystem at levels that are detrimental to its health, there is a greater incentive to evolve more efficient byproduct utilisation in more specialised industrial-ecological niches. Motivated primarily by the difficulty and expense of EfW APC residue disposal, but also in response to the need to conserve raw materials and energy in cement production, the use of APC residues as raw material feeds to the cement kiln (e.g., Krammart P. \& Tangtermsirikul S., 2004; Saikia N., et al, 2007; Ma, B.G., et al., 2000; Pan J.R., et al., 2008; Wang L., et al., 2010; Zhu F.F., et al., 2011; Lam C.H.K., et al., 2011;Wu K., et al., 2012), or to produce blended cement, has been proposed.

Viability of new opportunities for industrial symbiosis in the cement industry requires that: 1) the manufacturing process is not adversely affected or can be adapted, 2) the technical characteristics of the final cementitious material are appropriate to its intended application, and 3) the risks of negative impacts on health and/or the environment from manufacturing and use of the cementitious material are unchanged or reduced.

\subsection{Aims}

In this connection, this work aims to examine the potential role of EfW APC residues to produce blended cements, with a focus on the fate and behaviour of soluble toxic metals that are associated with fly ash, and therefore present in the APC residues.

\section{Approach}

A review of the literature regarding the use of EfW APC residues in blended cements has been conducted, and is placed in the overall context of industrial ecology and the use of pozzolanic wastes to produce blended cements. This is followed by a discussion of EfW APC residue composition and leachability of inorganic pollutants from APC residues and blended cement pastes and mortars that incorporate APC residues. The discussion concentrates on:

1) $\mathrm{pH}$-dependent leachability of pollutants from granular material. $\mathrm{pH}$ is a master variable for leaching, and information about pollutant solubility at alkaline (unadjusted), neutral and acid $\mathrm{pH}$ helps to characterise chemical controls on pollutant leaching, and indicates how a material will respond to inevitable changes in environmental $\mathrm{pH}$. Initial pollutant solubility is measured in a $24 \mathrm{~h}$ batch extraction of granular material at a liquid-to-solid (L/S) ratio of 10 with distilled water (e.g., according to BS EN 12457-2:2002). Additional batch extractions of a series of subsamples with different amounts of nitric acid (e.g., according to DD CEN/TS 15364: 2006) are used to measure pollutant solubility over the full $\mathrm{pH}$ range. Pollutant solubility is expressed in $\mathrm{mg}$ of pollutant leached per $\mathrm{kg}$ of dry material.

2) diffusion controlled leaching from monolithic specimens. The monolithic cement matrix provides a physical control on pollutant leaching; the hydraulic conductivity of a blended cement product used in a construction application will be sufficiently low that leaching can be expected to be controlled by diffusion. A monolithic specimen is suspended in deionised 
water, with periodic renewal of, and measurement of pollutant concentrations in, the leachate (e.g., according to EA NEN 7375:2004). The cumulative emission of pollutants, expressed in mg of pollutant per square metre of surface area of the monolithic specimens, is reported over time. Since leaching by diffusion may not prevail over the entire test period (e.g., in cases of contaminant wash-off, reaction or depletion), the test also includes provision to estimate a diffusion-controlled emission.

\section{Results}

\subsection{Use of Pozzolanic Wastes in Blended Cements}

Hydraulic cements based on calcium silicate hydrate (C-S-H) have been known since ancient times, and were created by reaction of natural and artificial pozzolans with lime before the invention of Portland cement in the early $19^{\text {th }}$ century. Pozzolanic wastes, such as ceramics, were used in cements and mortars by the ancient Greeks and Romans (e.g., Elsen J., 2006), and use of cements incorporating slags and ashes seems likely to have taken place since before the invention of Portland cement and has been documented from the early $20^{\text {th }}$ century (e.g., Griffths J.L., 1910; Jones M.R., et al., 2006). In the past several decades, replacement of Portland cement clinker with pozzolanic wastes.in blended cements has partly been determined by supply and demand. Despite the fact that some pozzolanic wastes can improve the technical performance of blended cements (e.g., Cembureau, 2013), there has been less uptake in periods of global over-capacity of clinker production. However, in times of high but volatile demand, blending of pozzolanic wastes with Portland cement reduces industry capital investment requirements and risk (Smith M.A., 1975). Currently, with a new 1Mtpa cement plant costing around $M \$ 200$, and demand for cement in Turkey, Malaysia and even parts of China forecast to peak in the next five years (Economist, 2013), the incentive for this practice remains high. Clinker fractions in global cement production are now $70-80 \%$, which has resulted in a decrease of about $20 \%$ in $\mathrm{CO}_{2}$ emissions/t of cement produced compared to the 1980s, when blended cements were uncommon (Olivier J.G.J., et al., 2012). In Europe, the most common material for blending is limestone, which is traditionally considered a diluent (Hawkins P., et al., 2003) and may be from waste sources, followed by the pozzolans ground granulated blast furnace slag (ggbs) and coal fly ash (i.e., pulverised fuel ash, pfa) (Cembureau, 2013). However, there is potential to produce blended, as well as clinker-less, cements with a wider range of wastes that are cementing, pozzolanic or can be alkaliactivated (e.g., Shi C., et al., 2011), such as steel slag (Forward G. \& Mangan A., 1999), rice husk ash (e.g., Mehta P.K., 1977), bagasse ash (e.g., Masood I. \& Mehrotra S.P., 1987) etc., subject to appropriate consideration of the technical and environmental consequences.

Production of blended cements with pozzolanic wastes is part of one of the earliest examples of an industrial ecosystem, at Kalundborg, Denmark, along with a refinery, plasterboard manufacturer, pharmaceutical plant, the local municipality and a power plant that provides pfa to the cement plant. The other ecosystem members share a variety of other resources (Lowe, E.A. \& Evans, L.K., 1995). Other case studies of industrial ecosystems that include blended cement production are Guitang, China (Zhu Q., et al., 2007), Kwinana and Gladstone, Australia (van Beers D., et al., 2007), and Kawasaki, Japan, (Van Berkel R., et al., 2009).

\subsection{Use of Energy from Waste Air Pollution Control Residues in Blended Cements}

Based on their thermal history and content of aluminosilicates (Table 1a), it seems conceivable for fly ash from EfW to be pozzolanic, or for APC residues, which contain excess lime from acid gas scrubbing as well as the fly ash, to be cementing, or both. A strength gain has in fact been observed for MSW fly ash in classical testing of pozzolanic reactivity, which monitors strength development of the test material mixed with lime or cement. However, this work showed that ash from high temperature combustion of refuse derived fuel (RDF, which concentrates MSW with high calorific value), was more pozzolanic than fly ash generated by combustion of ordinary MSW in a typical mass-burn incinerator (Hamernik, J.D. \& Frantz, G.C., 1991a). On the other hand, other testing of mass-burn MSW fly ash for pozzolanic activity on the basis of consumption of lime indicated that the fly ash was not pozzolanic (Fernandez E. et al., 1998). It is possible that these two different tests could come to different conclusions, as strength development could result from another reaction apart from reaction 
of aluminosilicates with lime to form $\mathrm{C}-\mathrm{S}-\mathrm{H}$, which is generally assumed to occur in pozzolans. Ettringite (Ubbrìaco P. \& Calabrese, D., 2000) as well as Friedel's salt (Remond et al. 2002b), have been observed as major phases in blended cements containing MSW fly ash; and could well contribute to the observed strength development.

Regardless of the cause of strength development in blended cements containing EfW APC residues or fly ash, it seems that variations in the quality of these materials are typical, and likely the result of variable combustion conditions and MSW composition. For example, RDF fly ash produced concrete with strengths comparable to a Portland cement control concrete at replacement levels up to $45 \%$ mass, whereas mass-burn MSW fly ash produced significantly lower concrete strengths (Hamernik J.D. \& Frantz G.C., 1991b). One study showed that higher mortar strengths resulted with up to $10 \%$ mass replacement of Portland cement by MSW fly ash (Goh C.C., et al., 2003), whereas another only found that partial replacement up to $10 \%$ mass does not significantly affect the compressive strength of cement and mortar (Siddique R., 2010); a third found that MSW fly ash has some cementitious activity, but "the reactivity is relatively lower" (Shi H., et al., 2006). Another stated that three different MSW fly ashes all "made the mortars properties worse" (Pavlik Z., et al., 2012).

All studies found that MSW fly ash addition to cement significantly increases the setting time (Hamernik J.D. \& Frantz G.C., 1991b; Remond S., et al., 2002a; Shi H., et al., 2006; Siddique R., 2010). Remond and co-workers (2002a) theorised that this effect is attributable to high concentrations of zinc and lead. This theory is consistent with findings that the better performing RDF fly ash contained lower concentrations of heavy metals than mass-burn MSW fly ash (Hamernik J.D. \& Frantz G.C., 1991a). Previous research has indeed established that heavy metals such as $\mathrm{Zn}, \mathrm{Pb}, \mathrm{Ni}$ and $\mathrm{Cu}$ are retarders of cement hydration and hardening at concentrations ranging from $\mathrm{mg} / \mathrm{kg}$ to several \%, as discussed in a meta-analysis by the author (Stegemann J.A. \& Buenfeld N.R., 2004). Remond (S., et al., 2002a) also reported that increased strength of mortars with up to $15 \%$ mass of replacement of cement with MSW fly ash displayed increased strength from 7 to $90 \mathrm{~d}$ curing. They attributed this to the acceleration effect of chloride at early ages (which has also been previously observed and is discussed in Stegemann J.A. \& Buenfeld N.R., 2004). However, strength reductions of these mortars were observed after 565 days. These workers did not explain this last observation, but Aubert and co-workers (2004a) found that small particles of metallic aluminium in blended cements containing MSW fly ash cause first an expansion reaction as the aluminium hydrolyses, and then lead to delayed ettringite formation that results in swelling, cracking and a decrease in compressive strength.

Higher proportions of MSW fly ash or APC residue are blended with Portland cement in waste treatment by stabilisation/solidification $(\mathrm{S} / \mathrm{S})$, which is intended to physically and chemically immobilise contaminants in a monolithic final product for safe disposal. For example, an EfW APC residue investigated with the author (Lampris C., et al., 2009) exhibited a minor tendency to self-cementing, developing a strength of about $1 \mathrm{MPa}$ in the absence of either lime or cement. However, the $28 \mathrm{~d}$ strength of paste with $50 \%$ cement replacement by EfW APC residue was only about a third of that of the Portland cement control, which indicates that the presence of the APC residue actually inhibited strength development. Similar results were found by Polettini (A. et al., 2001) with 10 to $80 \%$ cement replacement by MSW fly ash, though the effect was less after 90d. Both also found serious retardation of cement hydration. Lampris (C., et al., 2009) also found that cured blends with $20 \%$ cement content or less disintegrated when immersed in water, due to the dissolution of soluble salts in the APC residue. In other work, it was found to be necessary to use less than $5 \%$ EfW APC residue to avoid increased porosity of a monolithic specimen over time, due to leaching of soluble salts (Hall D.H., et al., 2005).

In recognition of the problems encountered in using raw EfW APC residues in blended cements, there has also been research on treatment of APC residues to improve their characteristics for use in blended cements, including washing (Collivignarelli C. \& Sorlini S., 2002; Aubert J.E., et al., 2004b; Bertolini L., et al., 2004; Gao X., et al., 2008; Wang L., et al., 2010b; Chen C.G., et al., 2013), and sintering or vitrification (Dyer T.D. \& Dhir R.K., 
2004; Lin K.L., 2005; Lee T.C. \& Rao M.K., 2009; Shih P.Y., et al., 2013). These studies are not further discussed here, except to note that the above review of the technical performance of blends of cement and MSW fly ash or EfW APC residues suggests that a fully beneficial treatment is likely to be non-trivial and must address multiple issues.

\subsection{Composition of Energy from Waste Air Pollution Control Residues and Portland Cement}

EfW APC residues are considered hazardous wastes in Europe, listed under code $190107^{*}$ in the European Waste Catalogue (EWC, European Commission Decision 2000/532/EC). The elemental composition of EfW APC residues is summarised in Table 1a, in comparison with similar information for Portland and blended cements. A comprehensive review of the global literature and laboratory investigation of eight UK EfW APC residues found APC residues to be highly complex materials, comprised of more than fifty minerals, where $\mathrm{CaCl}_{\mathrm{x}} \mathrm{OH}_{2-\mathrm{x}}$, $\mathrm{CaCO}_{3}, \mathrm{CaSO}_{4}$ and $\mathrm{Ca}(\mathrm{OH})_{2}, \mathrm{NaCl}$ and $\mathrm{KCl}$ are dominant. The solubility of UK EfW APC residues in a 100:1 extraction with distilled water ranged from 17-79\% total dry mass and pollutants were found to be distributed among many relatively soluble forms. For example, pollutants were associated with $\mathrm{CaCl}_{\mathrm{x}} \mathrm{OH}_{2-\mathrm{x}}$, which is highly soluble and transforms to $\mathrm{Ca}(\mathrm{OH})_{2}$ when leached with water, releasing $\mathrm{Cl}^{-}$and the incorporated pollutants (Bogush A. \& Stegemann J.A., 2013). The last column of Table 1a shows that potential pollutants, especially $\mathrm{Pb}$ and $\mathrm{Zn}$, but also $\mathrm{Cd}, \mathrm{Hg}, \mathrm{Sb}, \mathrm{Sn}$ and $\mathrm{Se}$, are enriched in APC residues relative to cements. Ba is enriched relative to Portland cements, but not other blended cements, as it is found in pfa. Apart from their potential to pollute the environment, metals in APC residues can affect cement hydration and hardening. Table 1a also shows high levels of several elements that are problematic for quality control of blended cements, notably chloride, which causes steel reinforcement corrosion, and alkalis $(\mathrm{Na}, \mathrm{K})$, implicated in the destructive alkalisilica reaction. Leaching of the soluble constituents can also be expected to impair the structural integrity of the material over time (see also 3.2).

The data suggest that, for the final $\mathrm{Pb}$ concentrations in blended cements to remain in the present range, EfW APC residues would typically need to be diluted by more than 10 to 100 times (neglecting the particularly high value reported by Eighmy T., et al. in 1995), whereas maintenance of low chloride concentrations would require more than 100 times dilution.

\section{4 pH Dependent Leaching of Energy from Waste Air Pollution Control Residues and Cements}

Table $1 \mathrm{~b}$ summarises results for granular batch leaching of EfW APC residues and an industrially stabilised EfW APC residue blended with Portland cement at unadjusted (alkaline) $\mathrm{pH}$. Leachate concentrations that exceed the European regulatory limits for acceptance of wastes to different types of landfill (last three columns) are marked. It can be seen that leachability of $\mathrm{Pb}$ and chloride is a concern for EfW APC residues, usually even for disposal in hazardous waste landfills, as well as $\mathrm{Se}, \mathrm{Zn}$ and sulphate; leachability of many pollutants is too high for inert landfill. Leachability of chlorides from the industrially stabilised APC residues containing cement is not improved, except slightly by dilution, and remains unacceptable even for hazardous waste landfill. However, leachability of metals can be seen to be much lower in the cement-stabilised sample, usually meeting the European criteria for disposal as stable non-reactive hazardous waste in a separate cell of a nonhazardous waste landfill. This effect is substantiated by other work (Yvon J., et al., 2006).

Figure 1 and Figure 2 further illustrate the differences in leachability of $\mathrm{Pb}$ and $\mathrm{Zn}$, respectively, from EfW APC residues (a) and commercial cement mortars (b). While the $\mathrm{pH}$ dependent leachability typical of amphoteric metals is observable in all cases, the solubility of both $\mathrm{Pb}$ and $\mathrm{Zn}$ is about two orders of magnitude lower in the cements than in the EfW APC residues. Similar trends for leaching of $\mathrm{Pb}$ and $\mathrm{Zn}$ from $\mathrm{EfW}$ APC residue and cements have been observed by other workers (e.g., Pb from EfW APC residues, including both incineration and gasification, defra, 2009; Zn from MSW APC residues, Polettini A., et al., 2001; Zn from cement, van der Sloot H.A., 2011). Although Figure 1 and Figure 2 do not show data for blended cements containing EfW APC residue, other data for $\mathrm{pH}$ dependent leaching of a blend of EfW APC residues with $28.6 \%$ total dry mass of Portland cement showed that $\mathrm{Pb}$ 
and $\mathrm{Zn}$ concentrations at alkaline $\mathrm{pH}$ values were about an order of magnitude lower for cement-treated samples, than for untreated residues (Geysen D. et al., 2004). These results are encouraging, in that they suggest that leaching is decreased and controlled by a different mechanism in samples containing cement. However, this conclusion should be treated with caution, as the amount of data for blended cements containing EfW APC residues remains 
Table 1a. Comparison of total concentrations of major and trace elements in cements and EfW APC residues

\begin{tabular}{|c|c|c|c|c|c|c|c|c|c|c|c|c|c|c|}
\hline \multirow[b]{2}{*}{ Source: } & \multicolumn{3}{|c|}{$\underline{\text { Portland Cements }}$} & \multirow[b]{2}{*}{ B (Average) } & \multirow{2}{*}{\multicolumn{2}{|c|}{ C (Range) }} & \multirow{2}{*}{$\frac{\text { Blended Cement }}{\mathrm{C}(\text { Range })}$} & \multicolumn{5}{|c|}{ EfW APC Residues } & \multirow{2}{*}{\multicolumn{2}{|c|}{$\begin{array}{c}\text { Enrichment } \\
\text { (APCR/cement) }\end{array}$}} \\
\hline & $\mathrm{A}(\mathrm{H}$ & (Range) & (Average) & & & & & $\mathrm{D}$ & $E$ & $\mathrm{~F}(\mathrm{R}$ & Range) & G (Average) & & \\
\hline \multicolumn{15}{|c|}{ Major elements (\%) } \\
\hline $\mathrm{Ca}$ & & & & & 29 & -46 & & 4.6 & 17 & $25-$ & $-\quad 35$ & 26 & 0.1 & -1 \\
\hline $\mathrm{Si}$ & & & & & 7.2 & -17 & & 3.8 & 11 & & - & - & 0.2 & -1.6 \\
\hline $\mathrm{Al}$ & & & & & 1.5 & -5.8 & & 2.1 & 3.9 & $1.0-$ & $-\quad 2.4$ & - & 0.2 & -3 \\
\hline $\mathrm{Fe}$ & & & & & 0.91 & -4.1 & & $<0.16$ & 2.8 & $0.30-$ & $\begin{array}{l}-\quad 0.72 \\
\end{array}$ & 1 & 0.1 & -3.1 \\
\hline $\mathrm{Na}$ & & & & & 0.03 & -1.0 & & 8.4 & 3.0 & $1.4-$ & $-\quad 2.3$ & 3.0 & 1 & -300 \\
\hline $\mathrm{K}$ & & & & & $<0.01$ & -1.5 & & 11 & 3.8 & $0.90-$ & $-\quad 2.4$ & 3.0 & 0.6 & -1100 \\
\hline $\mathrm{Mg}$ & & & & & 0.36 & -4.5 & & $<1.1$ & 1.6 & $0.40-$ & - $\quad 0.60$ & 0.6 & 0.1 & -5 \\
\hline $\mathrm{Mn}$ & & & & & 0.035 & -1.0 & & 0.05 & - & $0.04-$ & - $\quad 0.06$ & 0.05 & 0.0 & -2 \\
\hline $\mathrm{Ti}$ & & & & & 0.090 & -0.67 & & 0.61 & 0.4 & $0.09-$ & - $\quad 0.40$ & 0.14 & 0.1 & -7 \\
\hline $\mathrm{P}$ & & & & & 0.017 & -0.32 & & - & - & $0.15-$ & - $\quad 0.30$ & 0.44 & 0.5 & -25 \\
\hline $\mathrm{S}$ as $\mathrm{SO}_{4}{ }^{2-}$ & & & & & 2.3 & -5.6 & & - & 14 & 0.8 & & - & 0.1 & -6 \\
\hline $\mathrm{Cl}$ & & & & & $<0.01$ & -0.2 & & - & 10 & $13-$ & -22 & 17 & 70 & -2200 \\
\hline \multicolumn{15}{|c|}{ Trace elements (mg/kg dry mass) } \\
\hline As & 2 & -120 & 8 & 7 & 2 & -23 & $1.3-47$ & 960 & - & $10-$ & -210 & 27 & 0.1 & -700 \\
\hline $\mathrm{Ba}$ & & - & - & - & & - & $96-1400$ & $<2400$ & - & $70-$ & -400 & 360 & 0.1 & -4 \\
\hline $\mathrm{Cd}$ & 0.03 & -6 & 0.6 & 0.4 & $<0.1$ & -1 & $0.1-1.9$ & 1660 & 37 & $100-$ & -260 & 140 & 6 & -55000 \\
\hline Co & 3 & -21 & 11 & 8.7 & 6 & -22 & $2.3-23$ & 13.3 & - & $9.0-$ & $-\quad 18$ & 17 & 0.4 & -8 \\
\hline $\mathrm{Cr}$ & 25 & - 710 & 68 & 41 & 29 & -580 & $26-160$ & 494 & 16 & $12-$ & -200 & 80 & 0.02 & -20 \\
\hline $\mathrm{Cu}$ & 14 & -98 & 38 & 31 & 14 & -54 & $5.5-140$ & 2200 & 560 & $350-$ & - 920 & 480 & 2.5 & -400 \\
\hline $\mathrm{Hg}$ & & - & - & 0.06 & $<0.02$ & -0.1 & $<0.02-0.1$ & - & 36 & $<1-$ & $-\quad 34$ & - & 10 & -1800 \\
\hline Mo & & - & - & - & $<1$ & -8 & $1.5-14$ & 57 & - & $2.0-$ & - $\quad 16.0$ & 9.5 & 0.1 & -60 \\
\hline $\mathrm{Ni}$ & 14 & - 97 & 45 & 23 & 14 & -75 & $9.9-68$ & 70 & 71 & $15-$ & -45 & 35 & 0.2 & -7 \\
\hline $\mathrm{Pb}$ & 5 & -250 & 27 & 17 & 6 & -110 & $2.7-170$ & 27000 & 1500 & $2500-$ & - 5500 & 1600 & & - 10000 \\
\hline $\mathrm{Sb}$ & 0.5 & $-\quad 18$ & 5 & 2.9 & $<1$ & -5 & $1.1-23$ & - & - & $200-$ & -500 & 400 & & -1000 \\
\hline $\mathrm{Se}$ & & - & - & - & & - & - & 17 & - & $0.1-$ & -6.0 & 3.4 & & - \\
\hline $\mathrm{Sn}$ & 1 & -14 & 3 & 3.6 & $<1$ & -14 & $1-7$ & 5900 & - & $200-$ & - 800 & 400 & 14 & -5900 \\
\hline V & 15 & - 140 & 74 & 50 & 22 & -230 & $25-210$ & 32.5 & - & $<30$ & & 18 & 0.1 & -2 \\
\hline $\mathrm{Zn}$ & 21 & - 680 & 160 & 190 & 30 & - 380 & $16-370$ & 104000 & 3300 & $4000-$ & - 18500 & 6200 & 5 & -6500 \\
\hline
\end{tabular}


Table 1b. Leached concentrations of pollutants from raw and stabilised EfW APC residues in $24 \mathrm{~h}$ batch test with L/S=10 (e.g., EN 12457-2, mg/kg dry mass)

\begin{tabular}{|c|c|c|c|c|c|c|c|c|c|c|c|c|c|c|c|c|c|c|c|}
\hline \multirow{3}{*}{$\frac{\text { Source: }}{\mathrm{pH}}$} & \multicolumn{13}{|c|}{ EfW APC Residues } & \multirow{2}{*}{\multicolumn{3}{|c|}{$\frac{\text { APC/cement }>2}{\mathrm{I}}$}} & \multirow{2}{*}{\multicolumn{3}{|c|}{$\begin{array}{l}\text { European Regulatory Criteria } \\
\text { Inert Stable Non-reactive Hazardous }\end{array}$}} \\
\hline & E & & $\mathrm{F}$ & & & $\mathrm{G}$ & & & $\mathrm{H}$ & & & I & & & & & & & \\
\hline & - & 11.6 & - & 12.8 & 11.8 & - & 12.4 & 12.3 & - & 12.5 & 11.3 & - & 12.3 & 12.5 & - & 12.9 & & $>6$ & \\
\hline As & - & $<0.0005$ & - & 4 & 0.11 & - & 0.3 & 0.1 & - & 0.64 & 0.01 & - & 0.71 & 0.0001 & - & 0.0005 & 0.5 & 2 & 25 \\
\hline $\mathrm{Ba}$ & - & 10 & - & 45 & 8.2 & - & 13 & 19 & - & 32 & 11 & - & 39 & 1.0 & - & 99 & 20 & 100 & 300 \\
\hline $\mathrm{Cd}$ & 16 & $<0.5$ & & & 0.001 & - & 0.017 & 0.05 & & & 0.002 & - & 0.016 & 0.0001 & - & 0.002 & 0.04 & 1 & 5 \\
\hline Co & - & $<0.05$ & - & 0.15 & 0.09 & - & 0.19 & & - & & & - & & & - & & - & - & - \\
\hline $\mathrm{Cr}$ & 25 & 0.5 & - & 2.5 & 0.6 & - & 16 & 1.6 & - & 3.6 & 0.002 & - & 0.70 & 0.09 & - & 0.36 & 0.5 & 10 & 70 \\
\hline $\mathrm{Cu}$ & 82 & 1.3 & - & 3 & 0.49 & - & 3.4 & 1.6 & - & 2.7 & 0.06 & - & 9.9 & 0.0003 & - & 0.002 & 2 & 50 & 100 \\
\hline $\mathrm{Hg}$ & - & 0.04 & - & 0.5 & & - & & 0.10 & - & 0.17 & 0.0002 & - & 0.002 & 0.00003 & - & 0.003 & 0.01 & 0.2 & 2 \\
\hline Mo & - & $<1$ & - & 4 & 2.3 & - & 5.6 & 0.26 & - & 3.3 & 0.09 & - & 2.1 & 0.26 & - & 1.4 & 0.5 & 10 & 30 \\
\hline $\mathrm{Ni}$ & - & 0.2 & - & 4.5 & 0.24 & - & 0.57 & 0.57 & - & 1.8 & 0.002 & - & 0.01 & 0.0008 & - & 0.004 & 0.4 & 10 & 40 \\
\hline $\mathrm{Pb}$ & 270 & 300 & - & 700 & 33 & - & 740 & 66 & - & 211 & 0.92 & - & 1500 & 0.88 & - & 4.8 & 0.5 & 10 & 50 \\
\hline $\mathrm{Sb}$ & - & $<0.0001$ & - & 0.2 & 0.007 & - & 0.027 & 0.01 & - & 0.07 & 0.01 & - & 0.08 & 0.004 & - & 0.02 & 0.06 & 0.7 & 5 \\
\hline $\mathrm{Se}$ & - & $<0.0005$ & - & 9 & 1 & - & 3.2 & 0.25 & - & 3.5 & 0.02 & - & 0.1 & 0.0002 & - & 0.01 & 0.1 & 0.5 & 7 \\
\hline $\mathrm{Sn}$ & - & $<4$ & & & 0.004 & - & 0.055 & & - & & & - & & & - & & - & - & - \\
\hline V & - & 0.09 & - & 0.6 & 0.08 & - & 0.16 & & - & & & - & & & - & & - & - & - \\
\hline $\mathrm{Zn}$ & 560 & 40 & - & 85 & 15 & - & 110 & 7.9 & - & 100 & 1.4 & - & 52 & 0.10 & - & 0.65 & 4 & 50 & 200 \\
\hline $\mathrm{S}$ as $\mathrm{SO}_{4}^{2-}$ & - & 7000 & - & 12000 & 10000 & - & 20000 & & - & & 460 & - & 7200 & 140 & - & 16000 & 1000 & 20000 & 50000 \\
\hline $\mathrm{Cl}$ & - & 140000 & - & 170000 & 70000 & - & 220000 & & - & & 108000 & - & 157000 & 25000 & - & 44000 & 800 & 15000 & 25000 \\
\hline
\end{tabular}

Exceedance of regulatory criteria is indicated by italics for inert, bold for stable non-reactive, and bold, shaded for hazardous waste landfill.

A: Achternbosch M., et al., 2005 (range and average collected from the literature)

B: VDZ, 2005 (415 cements)

C: van der Sloot H.A., et al., 2011 (bulk composition for 56 worldwide cements; trace elements for 10 Portland cements and 17 blended cements)

D: Eighmy T. et al., 1995 (1 sample source)

E. Shi H.S. \& Kan L.L., 2009 (1 sample source)

F: Lewin K. \& Young C., 2004 (multiple samples from multiple sources, 2000-2004)

G: Bogush A. \& Stegemann J., 2013 (6 sample sources)

H: Ginés O., et al., 2009 (1 sample source)

I: defra, 2009 (BS EN12457-3; 1 EfW APC residue from incineration, 2 from gasification of MSW, 2 blends of APC residue from incineration with Portland cement) 


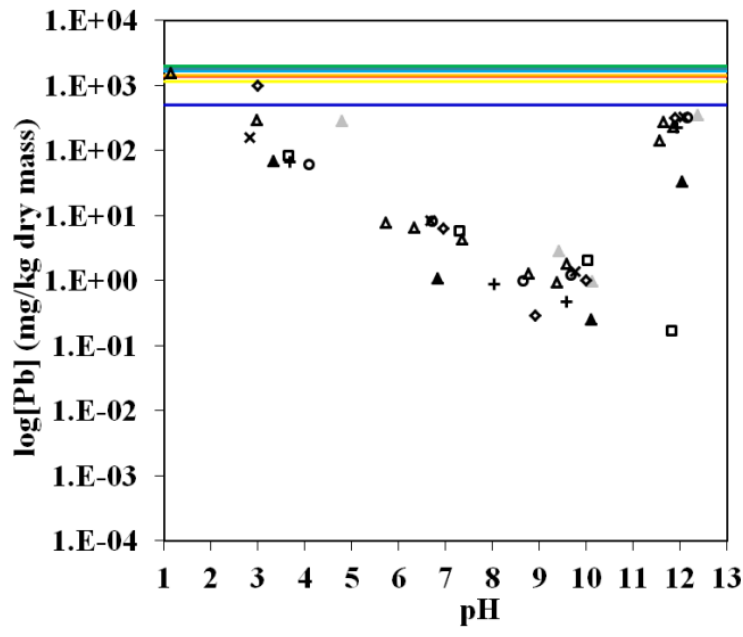

a)

Figure 1. pH dependent leaching of $\mathrm{Pb}$ from a) six EfW APC residues (Bogush A., et al., 2013), and b) cement mortars (van der Sloot H.A., et al., 2011). Straight horizontal lines indicate total concentrations.
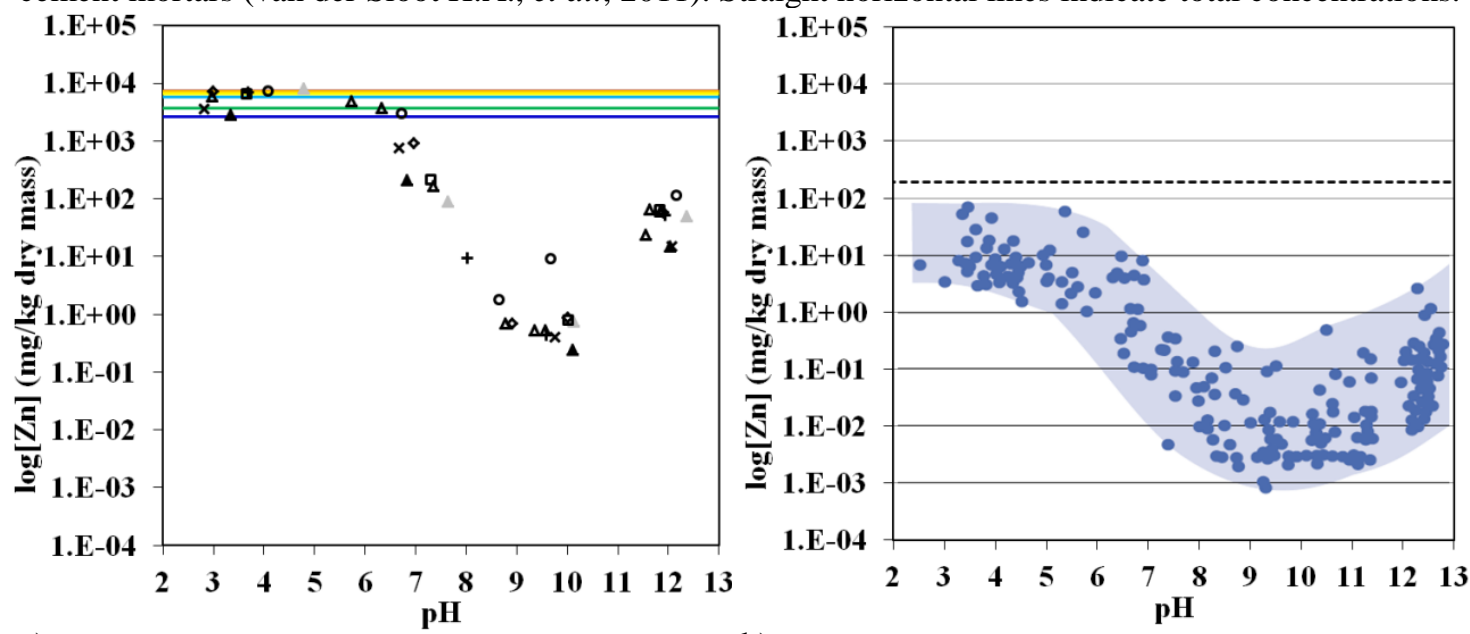

a)

b)

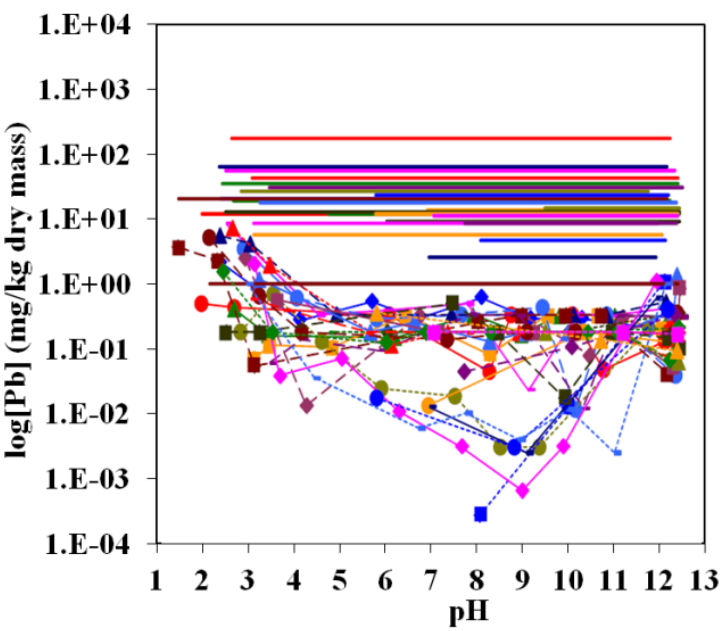

b)

Figure 2. pH dependent leaching of $\mathrm{Zn}$ from a) six EfW APC residues (Bogush A., et al., 2013), and b) 40 cement mortars (VDZ, 2005). Straight horizontal lines indicate total concentrations.

relatively limited, and the stabilisation effect may be subject to a concentration limit (e.g., for uptake of pollutants into cement hydration products).

\subsection{Diffusion-Controlled Leaching of Blended Cement Pastes Containing Energy from Waste Air Pollution Control Residues}

Table 2 summarises the cumulative $64 \mathrm{~d}$ emissions of various contaminants measured for monolithic specimens containing from 100 to $<5 \%$ total dry mass of EfW APC residue with Portland cement by several different researchers, in comparison with the worst case results for commercial cements. These data (which are also consistent with measured and calculated 64d chloride emissions of 860 and $3700 \mathrm{~g} / \mathrm{m}^{2}$ from Stegemann J.A., et al., 2005) show that the $64 \mathrm{~d}$ emission of chloride was in the order of $\mathrm{kg} / \mathrm{m}^{2}$. Clearly this represents an enormous loading on the environment for any application of a realistic size. At EfW APC residue loadings $>50 \%, 64 \mathrm{~d}$ emissions of metal contaminants were generally significantly higher than the maximum emissions from commercial cements. $64 \mathrm{~d}$ emission of $\mathrm{Pb}$ approached the range for commercial cements at 50\% cement replacement (also in data from Alba, N., et al., 2001), but emission of $\mathrm{Zn}$ remained elevated. For very low APC residue replacements $(<5 \%), 64 \mathrm{~d}$ metal emissions were in the range for commercial cements, but emission of chloride remained high. 


\section{Discussion \& Conclusions}

Comparing the global annual figures shows that EfW APC residue quantities (see 1.3) represent only about $0.1 \%$ of the raw materials needs for cements (see 1.2). Blending of EfW APC residues with Portland cement in this low proportion would result in sufficient dilution of toxic metal pollutants and even chlorides to avoid noticeably elevating their concentrations in the blended cements. However, the concept of using EfW APC residues as a legitimate cement replacement in an industrial ecosystem implies incorporation of larger quantities of APC residues in blended cements. Although leaching data for both granular and monolithic samples suggest that the mobility of low concentrations of metal pollutants is reduced in cement-based matrices, this is not the case for chloride. Furthermore, based on the technical data in the literature, the pozzolanic or cementing properties of EfW APC residues do not seem to be sufficiently strong or reliable to justify their use as a cement replacement, and there is also the potential for components of APC residues to cause other deleterious expansion reactions in cement-based materials. Reijnders (L., 2007) points out that pollutants present in wastes may pose a health risk to workers, and for sensitive applications such as water supply pipes, and that there is significant variability between sources so that the risk is difficult to assess. A wider analysis of resource flows in urban metabolism, including use of MSW fly ash in blended cements, also found that although "reusing fly ashes to produce the cement can reduce solid waste emissions and mineral ore demands... fly ash recycling needs more electric power, water and additives... Moreover, fly ash recycling will ... increase emissions of carbon dioxide and vehicle exhausts" (Liang S. \& Zhang T., 2012).

Table 2. Measured and calculated (*) cumulative pollutant emissions from blends of EfW APC residue and Portland cement, based on leaching under diffusion control, e.g., NEN 7375 (mg/m², except Cl)

\begin{tabular}{|c|c|c|c|c|c|c|c|c|c|c|c|}
\hline $\begin{array}{l}\text { Source: } \\
\text { Duration: } \\
\text { APCR \% } \\
\text { dry mass }\end{array}$ & 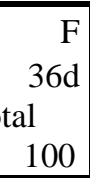 & $\begin{array}{r}J / K \\
64 d \\
90\end{array}$ & 80 & 50 & $64 d^{*}$ & 80 & 50 & $\begin{array}{r}I \\
64 d\end{array}$ & $>69$ & $\begin{array}{r}\mathrm{L} \\
64 \mathrm{~d}^{*} \\
<5\end{array}$ & $\begin{array}{r}\mathrm{M} \\
64 \mathrm{~d} \\
0\end{array}$ \\
\hline As & 4.6 & - & - & - & - & - & - & $<0.85$ & $<0.74$ & 0.02 & 3.5 \\
\hline $\mathrm{Ba}$ & 860 & - & - & - & - & - & - & 1000 & 690 & - & 168 \\
\hline $\mathrm{Cd}$ & 1.6 & - & - & - & - & - & - & $<0.023$ & $<0.023$ & 0.02 & 0.3 \\
\hline Co & - & - & - & - & - & - & - & $<0.036$ & $<0.036$ & - & 0.63 \\
\hline $\mathrm{Cr}$ & 19 & - & - & - & - & - & - & 3.7 & 9.7 & 2.7 & 6.2 \\
\hline $\mathrm{Cu}$ & 21 & - & - & - & - & - & - & $<0.14$ & 0.24 & 0.21 & 2.2 \\
\hline $\mathrm{Hg}$ & 0.2 & - & - & - & - & - & - & $<0.013$ & $<0.013$ & 0.02 & - \\
\hline Mo & 27 & - & - & - & - & - & - & 7.1 & 13 & 0.72 & 2.5 \\
\hline $\mathrm{Ni}$ & 36 & - & 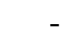 & - & - & - & . & $<0.12$ & $<0.15$ & 0.03 & 2.6 \\
\hline $\mathrm{Pb}$ & 590 & 72 & 43 & 8.4 & 47 & 40 & 6.8 & 30 & 31 & 0.19 & 7 \\
\hline $\mathrm{Sb}$ & 8 & - & - & - & - & - & - & 3.3 & 4.0 & 0.02 & 1.9 \\
\hline $\mathrm{Se}$ & 77 & - & - & - & - & - & - & 3.2 & $<3.2$ & 0.54 & 2.8 \\
\hline Sn & - & - & - & - & - & - & . & $<0.44$ & $<0.32$ & - & 2.5 \\
\hline V & - & - & - & - & - & - & - & $<0.08$ & $<0.08$ & - & 10 \\
\hline $\mathrm{Zn}$ & 8 & 48 & 35 & 24 & 74 & - & 24 & 10 & 13 & 0.78 & 3.8 \\
\hline $\mathrm{SO}_{4}{ }^{2-}$ & 3500 & - & - & - & - & - & - & 1600 & 7500 & 2000 & 1900 \\
\hline $\mathrm{Cl}\left(\mathrm{g} / \mathrm{m}^{2}\right)$ & 2090 & 1170 & 997 & 590 & 4300 & 3100 & 1420 & 1610 & 1660 & 2000 & 0.9 \\
\hline
\end{tabular}

F: Lewin, K. \& Young C., 2004 (field core from monofill of consolidated EFW APC residue)

I: defra, 2009 ( 2 blends of APC residue from incineration with Portland cement)

J: Lampris C., et al., 2009 (1 sample source)

K: Lampris C., et al., 2011 (1 sample source)

L: Hall D.H., et al., 2001 (1 sample source)

M: Van der Sloot H.A., et al., 2011 (maximum cumulative leached from $>50$ worldwide cements)

Arguably, worsening environmental impacts can sometimes be accepted if a practice clearly enhances other aspects of performance, but this does not seem to be the case for production of 
blended cements containing EfW APC residues. The concept that "dilution is not the solution to pollution" is a fundamental principle of modern waste management practice that is now firmly reinforced by legislation in most jurisdictions, e.g., EC Directive 2008/98/EC. Therefore, industrial ecology cannot solve the problem of management of EfW APC residues through incorporating them in blended cements without radically re-thinking the principles underlying waste management legislation. Relaxation of these principles would also have undesirable implications for numerous other hazardous wastes. Management of such wastes by blending into cements might be convenient, but could ultimately lead to wide uncontrolled dispersal of pollutants, especially in cement product recycling, and undermine the quality of blended cements.

\section{References}

-Achternbosch M.. et al., 2005. Impact of the use of waste on trace element concentrations in cement and concrete. Waste Management \& Research 23, 328-337.

-Alba N., et al., 2001. Stabilization/solidi®cation of MSW incineration residues from facilities with different air pollution control systems- Durability of matrices versus carbonation. Waste Management 21, 313-323.

-Aubert J.E., et al., 2004a. Metallic aluminum in MSWI fly ash: quantification and influence on the properties of cement-based products. Waste Management 24, 589-596. DOI:10.1016/j.wasman. 2004. 01.005.

-Aubert J.E., et al., 2004b. Use of municipal solid waste incineration fly ash in concrete, Cement and Concrete Research 34, 957-963. DOI:10.1016/j.cemconres.2003.11.002.

-Bertolini L., et al., 2004. MSWI ashes as mineral additions in concrete. Cement and Concrete Research, 34, 1899-1906. DOI:10.1016/j.cemconres.2004.02.001.

-Bogush A. \& Stegemann J.A., 2013. Zinc Speciation in Air Pollution Control Residues from UK Energy-from Waste Facilities (Report to the Environment Agency). Centre for Resource Efficiency \& the Environment, University College London.

-BS EN 12457-2:2002. Characterisation of waste - Leaching - Compliance test for leaching of granular waste materials and sludges - Part 2: One stage batch test at a liquid to solid ratio of $101 / \mathrm{kg}$ for materials with particle size below $4 \mathrm{~mm}$ (without or with size reduction).

-Cembureau, 2013. Cements for Low-Carbon Europe Through Clinker Substitution, 28p [on-line] On: http://www.cembureau.eu/cements-low-carbon-europe [Accessed 19 July 2013].

-Chen C.G., et al., 2013. The effects of the mechanical-chemical stabilization process for municipal solid waste incinerator fly ash on the chemical reactions in cement paste. Waste Management, 33, 858865. DOI: 10.1016/j.wasman.2012.12.014.

-Chertow M.R., 2000. Industrial symbiosis: Literature and taxonomy. Annual Review of Energy and the Environment, 25, 313-337. DOI: 10.1146/annurev.energy.25.1.313.

-Collivignarelli C. \& Sorlini S., 2002. Reuse of municipal solid wastes incineration fly ashes in concrete mixtures. Waste Management, 22(8), 909-912. DOI: 10.1016/S0956-053X(02)00085-5.

-Confederation of European Waste-to-Energy Plants (CEWEP) 2012. Waste-to-Energy in Europe in 2010 [on-line] On: http://www.cewep.eu/m_1040[Accessed 19 July 2013].

-Crow J.M., 2008. The concrete conundrum, Chemistry World, June, p. 62-66 [on-line] On: http://www.rsc.org/images/Construction_tcm18-114530.pdf [Accessed 19 July 2013].

-DD CEN/TS 15364:2006. Characterization of waste — Leaching behaviour tests - Acid and base neutralization capacity test.

-Department of Food \& Rural Affairs (defra), 2009. Characterisation of Residues from Industrial Processes and Waste Treatment, WR0110 [on-line] On: http://randd.defra.gov.uk/Default.aspx? Menu=Menu\&Module $=$ More $\&$ Location $=$ None $\&$ Completed $=0 \&$ ProjectID $=14674 \#$ RelatedDocuments [Accessed 31 July 2013].

-Dyer T.D. \& Dhir R.K., 2004. Hydration reactions of cement combinations containing vitrified incinerator fly ash. Cement and Concrete Research, 34(5), 849-856. DOI: 10.1016/j.cemconres.2003. 09.025 .

-EA NEN 7375:2004 Leaching Characteristics of Moulded or Monolithic Building and Waste Materials - Determination of Leaching of Inorganic Components with the Diffusion Test - 'The Tank Test' [English Translation][on-line]. On: http://www.environment-agency.gov.uk/static/documents/ Business/ea_nen_7375_2004_1026071.pdf [Accessed 31 July 2013].

-The Economist, 2013. The global cement industry-Ready-mixed fortunes- The world's cement giants look set for recovery - but will it be durable?, 22 June [on-line]. On: http://www.economist.com/ news/ 
business/21579844-worlds-cement-giants-look-set-recovery-but-will-it-be-durable-ready-mixedfortunes] [Accessed 19 July 2013].

-Eighmy T.T., et al., 1995. Comprehensive approach toward understanding element speciation and leaching behaviour in municipal solid waste incineration electrostatic precipitator ash. Environmental Science and Technology, 29, 629-46.

-Elsen J., 2006, Microscopy of historic mortars - a review. Cement and Concrete Research 36, 14161424. DOI:10.1016/j.cemconres.2005.12.006.

-European Council (EC) Directive 2008/98/EC of 19 November 2008 on waste and repealing certain Directives.

-Fernandez E., et al., 1998. Pozzolanic activity of incinerator residues of municipal solid waste, In: M. Cohen, S. Mindess, J. Skalny, ed., Materials Science of Concrete: the Sidney Diamond Symposium, Honolulu, 30 August-3 September, 1998, American Ceramic Society.

-Forward G. \& Mangan A., 1999. By-product synergy. The Bridge, 29(1), 12-15.

-Frosch R.A. \& Gallopoulos N.E., 1989. Strategies for Manufacturing. Scientific American 261(3) 144152.

-Griffiths J.L, 1910. Cement from blast furnace slag. Journal of Industrial and Engineering Chemistry 2, 561-562.

-Gao,X. et al., 2008. Utilization of washed MSWI fly ash as partial cement substitute with the addition of dithiocarbamic chelate. Journal of Environmental Management, 88(2) 293-299. DOI: 10.1016/ j.jenvman.2007.02.008.

-Geysen D. et al., 2004. Comparison of immobilization of air pollution control residues with cement and with silica/ Journal of Hazardous.Materials B, 107, 131-143.

-Ginés O., et al., 2009. Combined use of MSWI bottom ash and fly ash as aggregate in concrete formulation: Environmental and mechanical considerations. Journal of Hazardous Materials, 169, 643-650. DOI: 10.1016/j.jhazmat.2009.03.141

-Goh C.C., et al., 2003. Municipal Solid Waste Fly Ash as a Blended Cement Material. Journal of Materials in Civil Engineering, 15(6), 513-523. DOI: 10.1061/(ASCE(0899-1561(2003)15:6(513).

-Hall D.H., et al., 2005. Modelling in support of setting the waste acceptance criteria for monolithic waste, In: A. Al-Tabbaa \& J.A. Stegemann, ed., International Conference on Stabilisation/ Solidification for Treatment and Remediation, April, Cambridge, UK, Taylor \& Francis Group, London, ISBN 041537460 X, 107-116.

-Hamernik, J.D. \& Frantz, G.C., 1991a. Strength of concrete containing municipal solid-waste fly-ash. ACI Materials Journal, 88(5), 508-517.

-Hamernik, J.D. \& Frantz, G.C., 1991b. Physical and chemical properties of municipal solid waste fly ash. ACI Materials Journal, 88(3), 294-301.

-Hawkins P., et al., 2003. The Use of Limestone in Portland Cement: A State-of-the-Art Review, EB277, Portland Cement Association, Skokie, Illinois, 44p. On: http://www.cement.org/astmc01/ EB227.pdf [Accessed 20 December 2013].

-Hoornweg D. \& Bhada-Tata P., 2012. What a Waste: A Global Review of Solid Waste Management, World Bank Urban Development Series Knowledge Papers 68135 [on-line]. On: http://go.worldbank. org/BCQEP0TMO0 [Accessed 19 July 2013].

-International Energy Agency (IEA), 2012, Key World Energy Statistics [on-line]. On: http://www.iea. org/publications/freepublications/ publication/kwes.pdf [Accessed 19 July 2013].

-International Solid Waste Association, ISWA, 2006. Management of Bottom Ash from WTE PlantsAn overview of management options and treatment methods [on-line]. On: http://www.iswa.org/ uploads/tx_iswaknowledgebase/Bottom_ash_from_WTE_2006_01.pdf [Accessed 28 July 2013].

-Jones M.R. et al., 2006, Changes in coal fired power station fly ash: recent experiences and use in concrete. Ash Technology Conference. Birmingham (United Kingdom), 15-17 May [on-line]. On: http://www.ukqaa.org.uk/index_htm_files/AshTechA01ChangesInCoalFiredPowerStationJonesetal.pdf [Accessed 19 July 2013].

-Krammart P. \&Tangtermsirikul S., 2004. Properties of cement made by partially replacing cement raw materials with municipal solid waste ashes and calcium carbide waste. Construction and Building Materials, 18, 579-583.

-Lam C.H.K., et al., 2011. Utilization of municipal solid waste incineration ash in Portland cement clinker, Clean Technologies \& Environmental Policy, 13:607-615. DOI: 10.1007/s10098-011-0367-z.

-Lampris C., et al., 2009. Solidification/stabilisation of air pollution control residues using Portland cement: Physical properties and chloride leaching. Waste Management, 29(3), 1067-1075 DOI:10.1016/j.wasman.2008.08.006.

-Lampris C., et al., 2011. Metal leaching from monolithic stabilised/solidified air pollution control residues. Journal of Hazardous Materials, 185(2-3), 1115-1123. DOI:10.1016/j.jhazmat.2010.10.021. 
-Lee T.C. \& Rao M.K., 2009. Recycling municipal incinerator fly- and scrubber-ash into fused slag for the substantial replacement of cement in cement-mortars. Waste Management, 29(6) 1952-1959. DOI: 10.1016/j.wasman.2009.01.002.

-Lewin K. \& Young C., 2004. Characterisation of Air Pollution Control Residues from MSW EnergyFrom-Waste Facilities, WRc Report No. UC6763, Skipton (UK): Resource Recovery Forum.

-Liang S. \& Zhang, T., 2012. Comparing urban solid waste recycling from the viewpoint of urban metabolism based on physical input-output model: A case of Suzhou in China, Waste Management, 32 , 220-225. DOI: 10.1016/j.wasman.2011.08.018.

-Lin K.L., 2005. The influence of municipal solid waste incinerator fly ash slag blended in cement pastes. Cement and Concrete Research, 35(5), 979-986. DOI: 10.1016/j.cemconres.2004.06.011

-Lowe E.A. \& Evans L.K., 1995. Industrial ecology and industrial ecosystems. Journal of Cleaner Production, 3(1-2), 47-53.

-Ma B.G., et al., 2009. Research on sintering cement clinker by using the municipal solid waste incineration fly ash. Journal of Wuhan University of Technology, 31(8), 51-54.

-Masood I. \& Mehrotra S.P., 1987. Studies on non-conventional pozzolana-bagasse ash. Research and Industry, 32(3) 214-219.

-Mehta P.K., 1977. Properties of blended cements made from rice husk ash. Journal of the American Concrete Institute, 74(9), 440-442.

-Nisbet M.A., 2002. The Reduction of Resource Input and Emissions Achieved by Addition of Limestone to Portland Cement, PCA R\&D Serial No. 2086, Portland Cement Association, Skokie, USA [on-line]. On: http://www.cement.org/astmc01/Reference10.pdf [Accessed 19 July 2013].

-Olivier J.G.J., et al., 2012. Trends in global $\mathrm{CO}_{2}$ emissions- 2012 Report, PBL publication number: 500114022. PBL Netherlands Environmental Assessment Agency, The Hague/Bilthoven [on-line]. On: http://edgar.jrc.ec.europa.eu/CO2REPORT2012.pdf [Accessed 19 July 2013].

-Pan, J.R., et al., 2008. Recycling MSWI bottom and fly ash as raw materials for Portland cement. Waste Management, 28(7), 1113-1118. DOI: 10.1016/j.wasman.2007.04.009.

-Pavlik Z. et al., 2012. Environmental friendly concrete production using municipal solid waste incineration materials, In: Management of Natural Resources, Sustainable Development and Ecological Hazards III, Malaysia, 2011, WIT Transactions on Ecology and the Environment, 148, 325 334. DOI: 10.2495/RAV110301.

-Polettini A. et al., 2001. Properties of Portland cement-stabilised MSWI fly ashes. Journal of Hazardous Materials, B 88, 123-138.

-Reijnders, L., 2007. The cement industry as a scavenger in industrial ecology and the management of hazardous substances. Journal of Industrial Ecology, 11(3), 15-25.

-Remond S., et al., 2002a. Effects of the incorporation of municipal solid waste incineration fly ash in cement pastes and mortars: I.Experimental study. Cement and Concrete Research, 32, 303-11.

-Remond S. et al., 2002b. Effects of the incorporation of municipal solid waste incineration fly ash in cement pastes and mortars: II. Modeling. Cement and Concrete Research, 32, 565-576,

-Saikia N., et al., 2007. Production of cement clinkers from municipal solid waste incineration (MSWI) fly ash. Waste Management, 27, 1178-1189. DOI:10.1016/j.wasman.2006.06.004.

-Shi C., et al., 2011. New Cements for the 21st Century- The Pursuit of an Alternative to Portland Cement. Cement and Concrete Research, 41, 750-763. DOI:10.1016/j.cemconres.2011.03.016.

-Shi H., et al., 2006. Research on potential cementitious reactivity and immobilisation effect by Portland cement on MSW fly ash. Advances in Cement Research, 18(1), 35-40.

-Shi H.S. \& Kan L.L., 2009. Leaching behavior of heavy metals from municipal solid wastes incineration (MSWI) fly ash used in concrete. Journal of Hazardous Materials, 164, 750-754. DOI: 10.1016/j.jhazmat.2008.08.077.

-Shih, P.Y., et al., 2013. Characterization of a mortar made with cement and slag vitrified from a MSWI ash-mix and CMP sludge. Construction and Building Materials, 18, 22-30. DOI: 10.1016/j. conbuildmat.2012.07.083.

-Siddique R., 2010. Utilization of municipal solid waste (MSW) ash in cement and mortar. Resources, Conservation and Recycling, 54, 1037-1047. DOI:10.1016/j.resconrec.2010.05.002.

-Smith M.A., 1975. The economic and environmental benefits of increased use of pfa and granulated slag. Resources Policy, March 155-170.

-Stegemann J.A. \& Buenfeld N.R., 2004. Mining of existing data for cement-solidified wastes using neural networks. Journal of Environmental Engineering (ASCE), 130(5), 508-515. DOI:10.1061/ (ASCE)0733-9372(2004)130:5(508).

-Stegemann J.A., et al., 2005. The influence of aggregate on chloride diffusion from cement-based matrices. In: Cement and Concrete Science, 15-16 September, Royal Holloway College, UK. 
-Ubbrìaco P. \& Calabrese, D., 2000. Hydration Behaviour of Mixtures of Cement and Fly Ash with High Sulphate and Chloride Content. Journal of Thermal Analysis and Calorimetry, 61, 615-623.

-van Beers D., et al., 2007. Industrial symbiosis in the Australian minerals industries: the cases of Kwinana and Gladstone. Journal of Industrial Ecology, 11(1), 55-72.

-van Berkel R., et al., 2009. Quantitative Assessment of Urban and Industrial Symbiosis in Kawasaki, Japan. Environmental Science and Technology, 43(5), 1271-1281. DOI: 10.1021/es803319r.

-van der Sloot H.A., et al., 2011. Environmental Criteria for Cement Based Products - ECRICEM Phase I: Ordinary Portland Cement - Phase II: Blended Cements and methodology for impact assessment, ECN-E--11-020, Netherlands Energy Research Centre (ECN), Petten, The Netherlands [on-line] On: http://www.ecn.nl/docs/library/report/2011/e11020.pdf. [Accessed 31 July 2013].

-Verein Deutscher Zementwerke e.V. (VDZ), 2005. Umweltverträglichkeit von Zement und Beton [online] On: http://www.vdz-online.de/fileadmin/gruppen/vdz/3LiteraturRecherche/Taetigkeitsbericht/ VDZ_Kap_VI.pdf [accessed 31 July 2013].

-Vigon B., 2002. Toward a Sustainable Cement Industry Substudy 9: Industrial Ecology in the Cement Industry, Battelle/WBCSD [Online]. On: http://www.wbcsdcement.org/pdf/ battelle/final_report9.pdf [Accessed 29 August 2012].

-WBCSD, 2012. Cement Sustainability Initiative- Global Cement Database on CO2 and Energy Information- "Getting the Numbers Right" GNER [on-line]. On: http://www.wbcsdcement.org/index. $\mathrm{php} /$ key-issues/climate-protection/gnr-database [Accessed 19 July 2013].

-Wang L., et al., 2010a. Modeling of Zn migration during the co-processing of MSWI fly ash with cement kiln, In: J. Hao, J.H. Li and H.L. Hu, ed. Selected Proceedings of the 5th International Conference on Waste Management and Technology (ICWMT 5), Beijing, 15-17 December. 2010, 559594.

-Wang L., et al. 2010b. Recycling of municipal solid waste incineration fly ash for ordinary Portland cement production: A real-scale test. Resources, Conservation and Recycling, 54, 1428-1435. DOI: 10.1016/j.resconrec.2010.06.006.

-Wu K., et al., 2012. Preparation of alinite cement from municipal solid waste incineration fly ash, Cement \& Concrete Composites, 34(3) 322-327. DOI: 10.1016/j.cemconcomp.2011.11.016

-Zhu F.F., et al., 2011. The Calcination Process in a System for Washing, Calcinating, and Converting Treated Municipal Solid Waste Incinerator Fly Ash into Raw Material for the Cement Industry. Journal of the Air and Waste Management Association, 61(7), 740-746. DOI: 10.3155/1047-3289. 61.7.740.

-Yvon J., et al., 2006. Long-term stability in landfills of Municipal Solid Waste Incineration fly ashes solidified/stabilized by hydraulic binders, Journal of Geochemical Exploration, 90, 143-155. DOI: :10.1016/j.gexplo.2005.09.008.

-Zhu Q., et al., 2007. Industrial symbiosis in China: a case study of the Guitang Group. Journal of Industrial Ecology 11 (1), 31-42. 